\title{
Effects of canopy removal on the understory algal community structure of coastal forests of Macrocystis pyrifera from southern South America
}

\author{
B. Santelices and F. P. Ojeda \\ Departamento de Biología Ambiental y de Poblaciones, Facultad de Ciencias Biológicas, Pontificia Universidad Católica de \\ Chile, Casilla 114-D, Santiago, Chile
}

\begin{abstract}
Communities with similar physiognomy often have been expected to show similar ecological responses to experimental manipulations. This is the case in geographically disjunct communities of Macrocystis pyrifera, most of which have been described as showing notoriously similar patterns of vegetational stratification. Comparison of the ecological responses of the second and third vegetational strata to the removal of the floating canopy of $M$. pyrifera in forests in southern Chile point to differences with equivalent experiments performed in the northern Pacific. In southern Chile the second stratum which is formed by Lessonia flavicans decreases in biomass representation after removal of the floating $M$. pyrifera canopy. The third stratum contains a number of fugitive species which are replaced by a numerically similar group of fugitive species after removal of the floating $M$. pyrifera canopy. The presence of perennial species in the third stratum seem unaffected by light changes resulting either from seasonal variation or from removal of the floating canopy. Total number of understory algal species in the forests from southern Chile is lower compared to giant kelp forests in California. Canopy removal does not significantly change the total number of species, although it changes the specific component in each experimental area. Thus, the ecological response of the understory algal community to the removal of the floating canopy of $M$. pyrifera in southern Chile seems less dramatic than that which has been described for similar communities in the North Pacific Ocean.
\end{abstract}

\section{INTRODUCTION}

Vegetational stratification is a physiognomic characteristic of most kelp communities, including the several geographically disjunct forests of Macrocystis pyrifera. Although climatic and topographic conditions may locally modify the number of algal strata or the values of algal abundance and diversity within each stratum, there seems to be notorious similarities in the patterns of stratification found in the several forests of M. pyrifera so far investigated (Andrews, 1945; Cribb, 1954; McLean, 1962; Aleem, 1956, 1973; Dawson et al., 1960; North, 1968, 1971; Kuhnemann, 1970; Dayton et al., 1973; Dayton, 1974; Barrales and Lobban, 1975; Foster, 1975a, b; Yellin et al., 1977; Pearse and Hines, 1979; Reed and Foster, in press).

Correlative studies in the forests of Macrocystis pyrifera from the North Pacific indicate that decreased light conditions due to light trapping by the floating canopy could significantly affect community structure of the underlying strata (Neushul, 1965; Foster, 1975b). Experimental removal of the canopy of $M$. pyrifera in the Californian communities have resulted in biomass increments of other Laminariales occurring in the underlying strata together with significant increases of the wet weight of the ground cover foliose red algae (Pearse and Hines, 1979; Reed and Foster, in press). Comparative studies have been attempted in forests of $M$. pyrifera from South America but logistic difficulties have hindered the gathering of accurate data. Canopy cutting of $M$. pyrifera in the forests of southern Chile seemingly resulted in a marked increase of understory algal pópulations (Dayton, 1974) but specific information on spatial or temporal changes of these species is missing.

In spite of the absence of experimental data from southern South America, Barrales and Lobban (1975) recognized Macrocystis pyrifera as a 'foundation 
species' (sensu Dayton, 1972) and predicted that the loss of $M$. pyrifera would mean the elimination of a great many plants and animals and drastic changes in the structure of the resulting community. However, losses of $M$. pyrifera individuals is a naturally occurring phenomenon in these forests where naturally cleared spots can reach several dozen meters in diameter (Santelices and Ojeda, 1983). Examination of the understory vegetation in such areas indicated only slight modifications in community structure as compared with the vegetation occurring underneath the $M$. pyrifera canopy. This motivated a detailed experimental study on the effects of canopy removal on timespace distributional and production pattern of the understory algal vegetation in the giant kelp forest of Puerto Toro, Navarino Island, southern Chile.

\section{MATERIALS AND METHODS}

\section{Study site}

Puerto Toro, on the west side of Navarino Island $\left(53^{\circ}\right.$ $07^{\prime} S_{i} 72^{\circ} 00^{\prime} \mathrm{W}$ ) was selected as study site. A detailed account of the geographic and climatic conditions as well as the structure of these forests of Macrocystis pyrifera has been reported by Santelices and Ojeda (1983). The forests of $M$. pyrifera are narrow, sheltered coastal belts quite homogeneous in canopy cover, quite regular in size and distribution pattern of the $M$. pyrifera individuals, with relatively homogeneous substratum distribution down to $8 \mathrm{~m}$ depth and with several strata of algal vegetation. The first such stratum is represented by the floating canopy of $M$. pyrifera. The second is formed by 2 to $3 \mathrm{~m}$ long plants of Lessonia flavicans which extend across most of the forest. Underneath this canopy a third algal stratum is formed by fleshy and frondose algae of about $50 \mathrm{~cm}$ height, among which Gigartina skottsbergii and Epymenia flaklandica are the commonest and most important biomass producers, covering extended portions of the forest. Occasionally, elongated individuals of Enteromorpha prolifera, Scytosiphon lomentaria, tufts of Halopteris hordacea, Spongomorpha pacifica, Ballia callitrichia and Plocamium secundatum, as well as elongated blades of Ulva rigida, Callophyllis variegata, Hymenena laciniata, Myriogramme sp. and phycodrys sp. can be found forming associations covering localized patches in the bed. In areas where the canopy of $M$. pyrifera or L. flavicans is less dense, a cover of short, filamentous members of the genera Ectocarpus, Ceramium, Griffithsia and Lophurella can be found as well. Most of the primary substratum across the bed is covered by crustose calcareous algae which occur underneath the above mentioned strata.

\section{Experimental treatments}

To test for the effects of canopy removal on structure, abundance and diversity of the understory algal vegetation, two $5 \mathrm{~m}$ wide, $50 \mathrm{~m}$ long transects were set across the bed of Macrocystis pyrifera. Each transect extended from the shallower to the deeper end of the bed of $M$. pyrifera and was separated from the next by a $10 \mathrm{~m}$ distance.

In September 1979, the understory algal vegetation occurring along both transects was sampled simultaneously to check for similarity in algal vegetation. A permanent diving line was extended along the central part of each transect and was divided into ten, $5 \mathrm{~m}$ long by $5 \mathrm{~m}$ wide sampling areas. The second vegetational stratum was sampled using one $2 \mathrm{~m}^{2}$ rectangular quadrat that was haphazardly placed inside each $25 \mathrm{~m}^{2}$ sampling area. The third vegetational stratum was sampled using two, $1 \mathrm{~m}^{2}$ square quadrats, each one placed at each side of the central transect line within the $25 \mathrm{~m}^{2}$ sampling area.

In early November 1979 the floating canopy of $\mathrm{Ma}$ crocystis pyrifera was cut down to $1 \mathrm{~m}$ below the water level during low tide along one of the transects. Canopy removal included the fronds of $M$. pyrifera individuals found inside the transects as well as the canopy of marginal individuals which could reach the cleared area by currents. The relatively small size of the $M$. pyrifera individuals in these forests $(\bar{x}=10.8 \pm 4.8$ [SD] $\mathrm{m}$ long) facilitated this procedure. A total of $950 \mathrm{~kg}$ of wet biomass were harvested in the approximately $250 \mathrm{~m}^{2}$ of cleared surface.

Removal of the canopy of Macrocystis pyrifera was repeated in the experimental area in January and April 1980 in order to eliminate the growth of $M$. pyrifera which had occurred since the last removal. From November 1979 to January 1980 a total of $198.5 \mathrm{~kg}$ of wet biomass had been produced covering an estimated one sixth of the previously cleared surface. In April 1980 , one fourth of the previously cleared surface was found covered by $325 \mathrm{~kg}$ of wet fronds growing mainly from individuals along the border of the transect. The last visit, performed in July 1980 revealed less than one fifth of the cleared surface being covered by growth of the $M$. pyrifera canopy. No canopy removal was performed at this time.

Field observations and photographic evidence of the non-removal transect revealed no major change in canopy cover from September 1979 to July 1980 other than a reduction of the deepest end of the belt during winter (Santelices and Ojeda, 1983). During that time canopy surface cover values in the non-removal area ranged from 98 to $95 \%$.

A comparison of irradiance values between the areas with and without canopy (using a Li-cor Model LI-185 
quantum meter) performed in May 1980 (Santelices and Ojeda, 1983) indicated the Macrocystis pyrifera canopy could reduce subsurface light intensities to between one seventh to one tenth that found at the same depth without canopy.

Sampling for changes in understory algal vegetation (second and third strata) was performed simultaneously along both transects as described previously during late November, January, late April and July. The macroalgae harvested in the quadrats were preserved in a $7 \%$ formaldehyde solution in seawater and transported in previously labelled plastic bags to the laboratory. There, the algae were sorted by species and weighed wet. Identification to species level could not be completed in several cases due to the lack of fertile individuals.

\section{RESULTS}

\section{Temporal pattern of species distribution}

Non-removal area

The temporal variation of the occurrence of the 32 commonest macro-algal species found in the coastal forests of Macrocystis pyrifera in Puerto Toro are summarized in Table 1 . The 32 species constitute $92.0 \%$ of

Table 1. Presence of understory algal species found at the removal and non-removal transects in the forest of Macrocystis pyrifera in Puerto Toro, Navarino Island, southern Chile. (S: September; N: November, 1979; J: January; A: April; J; July, 1980; +: presence). Presence indicates occurrence of a given species at any one of twenty $1 \mathrm{~m}^{2}$ quadrats placed every $5 \mathrm{~m}$ along each transect

\begin{tabular}{|c|c|c|c|c|c|c|c|c|c|c|}
\hline \multirow[t]{2}{*}{ Species } & \multicolumn{5}{|c|}{ Non-removal } & \multicolumn{5}{|c|}{ Removal } \\
\hline & $\mathrm{S}$ & $N$ & $\mathrm{~J}$ & A & $\mathrm{J}$ & $\mathrm{S}$ & $\mathrm{N}$ & $\mathrm{J}$ & A & $\mathrm{J}$ \\
\hline Juveniles of Macrocystis pyrifera (Linnaeus) C. Agardh & + & + & + & + & + & + & + & + & + & + \\
\hline Lessonia flavicans Bory & + & + & + & + & + & + & + & + & + & + \\
\hline Halopteris hordacea (Harvey) Sauvageau & + & + & + & + & + & + & + & + & + & + \\
\hline Plocamium secundatum (Kützing) Kützing & + & + & + & + & + & + & + & + & + & + \\
\hline Gigartina skottsbergii Setchell et Gardner & + & + & + & + & + & + & + & + & + & + \\
\hline Epymenia falklandica Taylor & + & + & + & + & + & + & + & + & + & + \\
\hline Delesseria sp. & + & + & + & + & + & + & + & + & + & + \\
\hline Ceramium involutum Kützing & + & + & + & + & + & + & + & + & + & + \\
\hline Callophyllis variegata (Bory) Kützing & + & + & + & + & + & + & + & + & + & + \\
\hline Ballia callitricha (C. Agardh) Kutzing & + & + & + & + & + & + & + & + & + & + \\
\hline Spongomorpha pacifica (Montagne) Kützing & & + & & & & & + & + & + & \\
\hline Antithamnion sp. & & + & & & & & & & & \\
\hline Iridaea $\mathrm{sp}$ & & + & & & & & & & & \\
\hline Polysiphonia flabelliformis Hooker et Harvey & & + & & & & & & & & \\
\hline Scytothamnus fasciculatus (Hooker et Harvey) Cotton & & + & & & & & & + & & \\
\hline Codium sp. & & + & & & & & + & & + & + \\
\hline Enteromorpha prolifera (Müller) J. Agardh & & + & & & & & & & & \\
\hline Ceramium rubrum (Hudson) C. Agardh & & + & + & & & & & + & & \\
\hline Picconiella plumosa (Kylin) De Toni & & + & + & & & & + & + & + & \\
\hline Juveniles of Lessonia vadosa Searles & & + & + & & & & & & & \\
\hline Enteromorpha bulbosa (Suhr) Montagne & & + & + & + & & & & & & \\
\hline Ulva rigida (C. Agardh) Thuret & & + & + & + & & & + & + & + & \\
\hline Chondria sp. & & & + & & & & & & & \\
\hline Hymenena laciniata Hooker et Harvey & & & + & & & & + & + & & + \\
\hline Lophurella patula (Hooker et Harvey) De Toni & & & + & & & & & & & + \\
\hline Tiffaniella sp. & & & + & & & & + & + & & \\
\hline Cladosthele decaisnei Hooker et Harvey & & & + & & & & & + & & \\
\hline Sphacelaria sp. & & & + & & & & & & & \\
\hline Phaeoglossum sp. & & & + & & & & & & & \\
\hline Griffithsia sp. & & & + & + & & & & & & \\
\hline Myriogramme sp. & & & + & + & & & + & + & + & \\
\hline Rhizoclonium sp. & & & & & + & & & & & \\
\hline Callithamnion sp. & & & & & & & & & & + \\
\hline Phycodrys sp. & & & & & & & + & + & & \\
\hline Pterosiphonia sp. & & & & & & & + & + & & \\
\hline Zonaria sp. & & & & & & & + & + & & \\
\hline Scytosiphon lomentaria (Lyngbye) Endlicher & & & & & & & & + & & \\
\hline Ectocarpus sp. & & & & & & & & + & & \\
\hline Rhodymenia sp. & & & & & & & & + & & \\
\hline Adenocystis utricularis (Bory) Skottsberg & & & & & & & & + & + & + \\
\hline Total number & 10 & 22 & 24 & 14 & 11 & 10 & 20 & 26 & 16 & 15 \\
\hline
\end{tabular}


the total biomass collected in the forest. A group of 10 taxa (juveniles of $M$. pyrifera, Lessonia flavicans, Halopteris hordacea, Plocamium secundatum, Gigartina skottsbergii, Epymenia falklandica, Delesseria sp., Ceramium involutum, Callophyllis variegata and Ballia callitricha) was found in all samples and seemingly constitutes permanent populations in the second and third vegetational strata. The finding of the remaining 22 species was restricted to some months of the year. Enteromorpha bulbosa and Ulva rigida disappear in July while Rhizoclonium sp. was found only during that month. Six species were found only during November while 7 were found only in January. The presence of the remaining 6 species included the November and January samples and seemingly they occur in the forest during spring and summer. The total number of species varies along time with maximum values during November and January, which correspond to spring and summer.

\section{Removal area}

In the removal transect, maximum and minimum species richness occurred also in a summer and a winter month respectively. The total number of species (29) is quite similar to the total found in the nonremoval area. Strict similarity in temporal pattern of species composition and distribution is however linited to the 10 perennial species. In the removal transect, these 10 species were also found in every month collected and seemingly they also constitute permanent populations in the absence of canopy of Macrocystis pyrifera. The presence of these species appears thus not to be affected by light variations produced either by seasonal climatic changes or by the removal of the canopy of $M$. pyrifera.

The pattern of temporal distribution of nearly all other species found in the removal area was different from the pattern shown in the non-removal transect. A group of 11 species found underneath the canopy during November and January was never found in the removal transect (Antithamnion sp., Iridaea sp., Polysiphonia flabelliformis, Enteromorpha prolifera, Chondria sp., Lessonia vadosa, Sphacelaria sp., Phaeglossum sp., Griffithsia sp., Rhizoclonium sp. and Enteromorpha bulbosa). This group of species apparently was replaced by 8 other species which were found exclusively in the area without a canopy of Macrocystis pyrifera, and included Callithamnion sp., Phycodrys sp., Pterosiphonia sp., Zonaria sp., Scytosiphon lomentaria, Ectocarpus sp., Adenocystis utricularis and Rhodymenia sp. Eight other species were found in both transects but with different temporal occurrence. Five of them (Codium sp., Piconiella plumosa, Hymenena laciniata, Myriogramme sp. and Spongomorpha pacifica) had more extended temporal occurrence in the removal transect; the opposite was true with Ceramium rubrum. Scytothamnus fasciculatus and Lophurella patula was found later in the year in the removal area than underneath the canopy of $M$. pyrifera.

\section{Spatial pattern of species distribution}

\section{Non-removal area}

The spatial pattern of mean annual biomass distribution of the 32 commonest understory algal species occurring across the forest of Macrocystis pyrifera in Puerto Toro are summarized in Fig. 1. Species such as Chondria sp., Sphacelaria sp., Scytothamnus sp., Ballia callitricha, Ceramium involutum, Plocamium secundatum, Rhizoclonium sp. and Codium sp. are restricted to the shallower end of the forest. A second group of species, including Phycodrys sp., Iridaea sp., Spongomorpha pacifical, Antithamnion sp., Enteromorpha prolifera, Polisiphonia flabelliformis and Ceramium rubrum were found only in the middle portion of the forest while species such as Cladothele decaisnei, Griffithsia sp., Tiffaniella sp., Hymenena laciniata, Lophurella patula and the juveniles of Macrocystis pyrifera are preferentially found at the deepest end of the bed. The remaining 12 species occurred across most of the belt, frequently appearing in almost any station sampled. Most of the biomass conforming the understory algal vegetation is produced by these species and specially by Lessonia flavicans, Gigartina skottsbergii and Epymenia falklandica. It is interesting to note that the maximum biomass of each one of these 3 species occurs in different parts of the forest. Maximum biomass of Gigartina skottsbergii occurs at the shallower end of the forest, maximum values for $L$. flavicans are at the most central part of the forest while maximum biomass of $E$. falklandica occurs at the deeper end of the forest. The negative correlation values of biomass are statistically significant for the $G$. skottsbergii - E. falklandica relationship (Spearman Rank Coefficient, $\left.r_{s}=-0.72, p<0.05\right)$.

\section{Removal area}

The removal of the canopy of Macrocystis pyrifera changes the patterns of biomass production and species distribution across the forest (Fig. 2). Only 10 species have a clearly zonated distribution pattern in the removal area while 7 species extend from the shallower to the middle part of the forest and 13 species extend across the whole forest. 


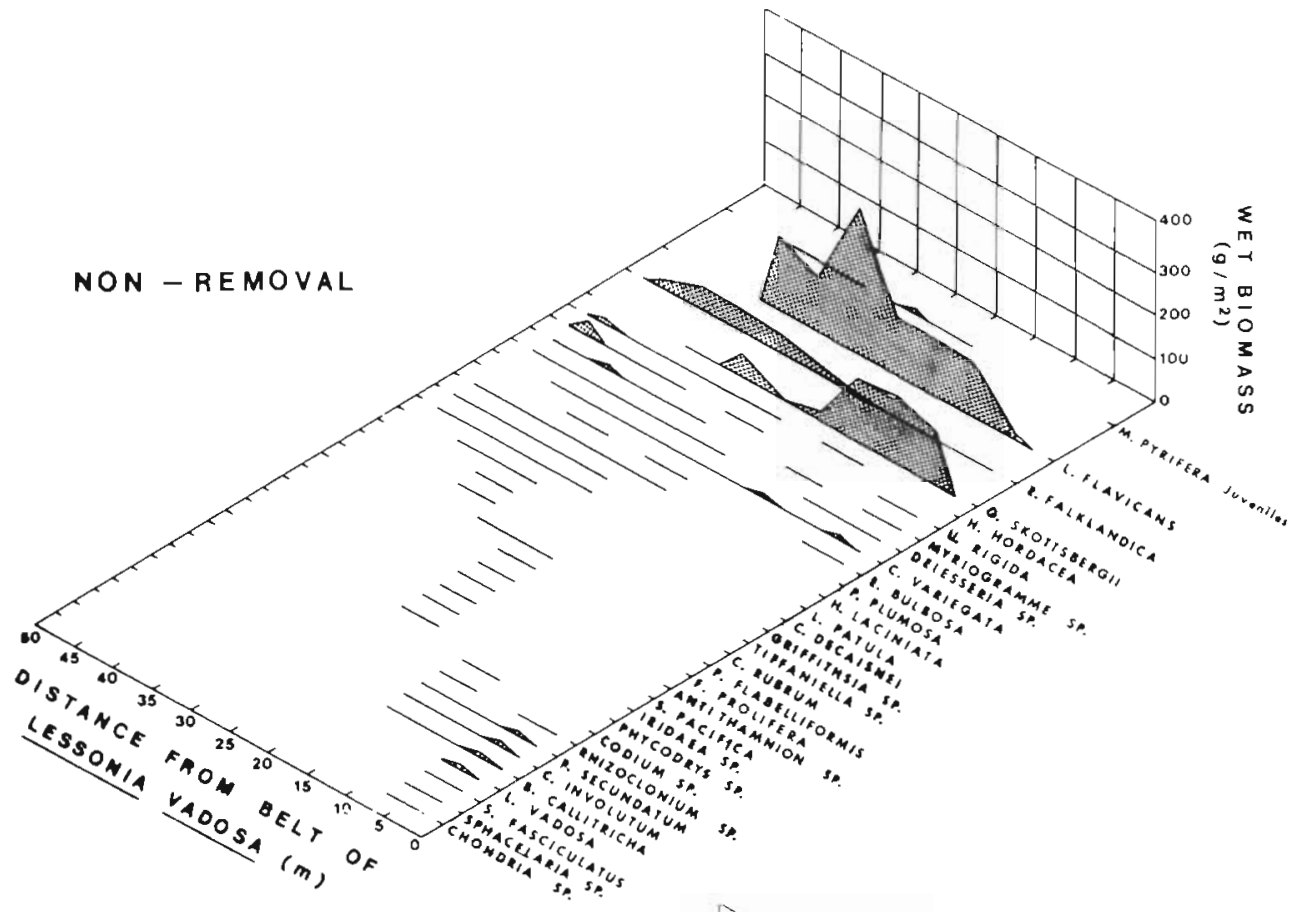

Fig. 1. Patterns of biomass distribution of the $32 \mathrm{com}$ monest understory algal species found in the forest of Macrocystis pyrifera (non-removal area) in Puerto Toro. Biomass data are average values of 80 quadrats. They were collected along a $50 \mathrm{~m}$ long transect during 4 sampling programs (November 1979, January, April and July 1980). Two replicate quadrats were used each time for each of the 10 sampling stations located every $5 \mathrm{~m}$ along each transect

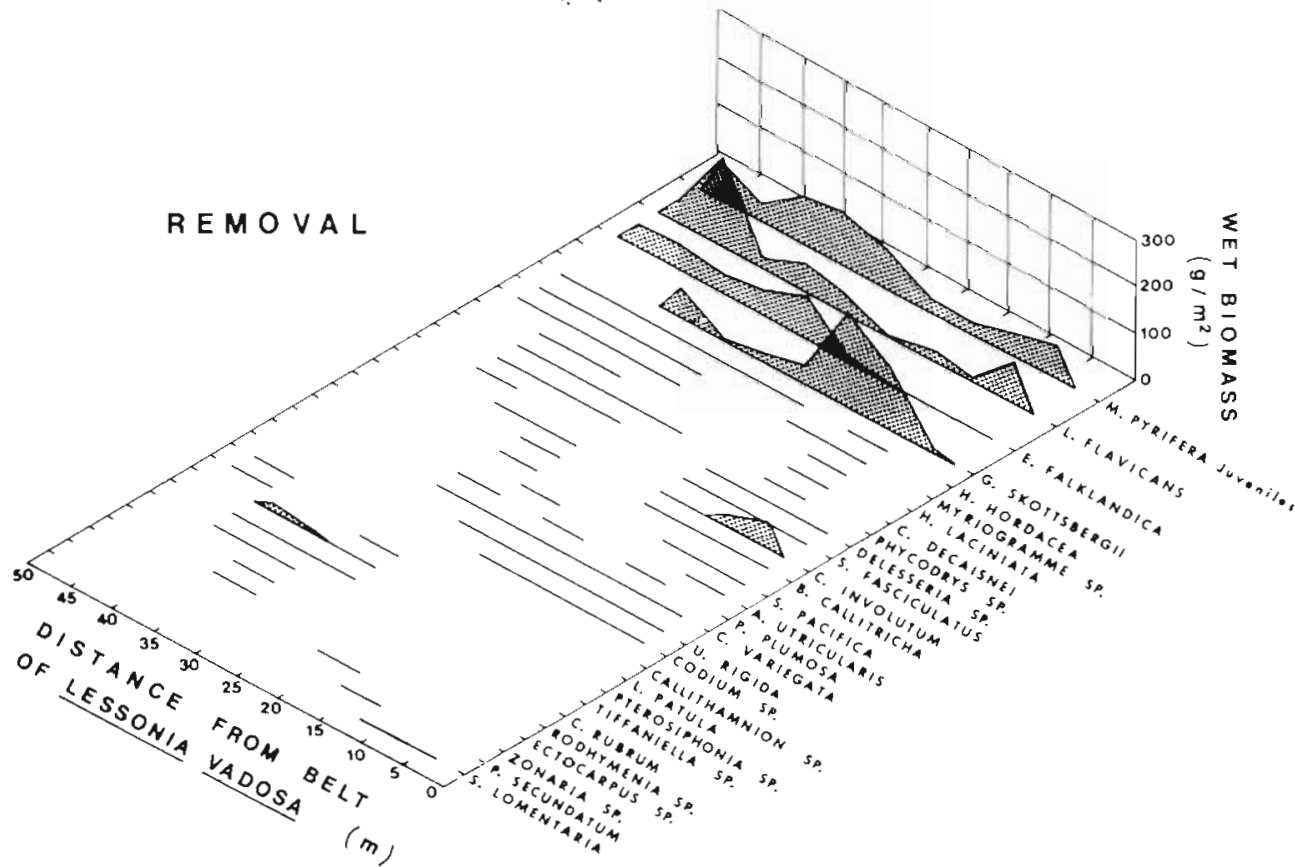

Fig. 2. Patterns of biomass distribution of the 29 commonest understory algal species found in the forest of Macrocystis pyrifera (removal area) in Puerto Toro. Data obtained as explained in legend to Fig. 1

The relative contribution of some of the most important biomass producers also varies. This is the case of the juveniles of Macrocystis pyrifera whose representation increases across most of the forest in the removal area. By contrast, the annual average biomass values of Lessonia flavicans decreased specially in the shallower and middle portion of the forests. In the case of Epymenia falklandica and Gigartina skottsbergii, there is no significant change in average biomass representation from one transect to the other and the negative correlation in biomass distribution of the 2 species is also found in the transect devoid of canopy (Spearman Rank Coefficient, $r_{s}=-0.69, p<0.01$ ).

\section{Temporal and spatial patterns of biomass distribution}

\section{Non-removal area}

There is a clear temporal change in the biomass of the underlying strata underneath the canopy of $\mathrm{Ma}$ crocystis pyrifera which results mainly from significant 
increments in the stock of Lessonia flavicans specially in the middle portions of the bed during January (Fig. 3 and 4). Even though there is some temporal and spatial variation in the biomass values of the other 3 important producers, such changes do not display a regular pattern. The zonated pattern of distribution of Gigartina skottsbergii and Epymenia falklandika occurs during all months collected. Slight increments in stocks of G. skottsbergii occur in July and November mainly in the shallower parts of the forest. By contrast, the increments of standing stock of Epymenia falklandica are restricted to the deeper parts of the forest (Fig. 3).

\section{Removal area}

The biomass increments shown by Lessonia flavicans during January in the non-removal area is miss- ing in the removal transect (Fig. 3). Since this is the most important understory producer, the removal of the canopy of Macrocystis pyrifera results in absence of seasonal change of total biomass distribution (Fig. 4). The increments in biomass shown by the juveniles of M. pyrifera (Fig. 3) did not compensate for the reduction of $L$. flavicans during the time of study. The patterns of distribution of Epymenia falklandica and Gigartina skottsbergii do not show any significant departure from the mutually exclusive trend described for the non-removal transect.

\section{DISCUSSION}

Even though the forest of Macrocystis pyrifera from Puerto Toro shows vegetational stratification similar to the pattern described for the Californian forests
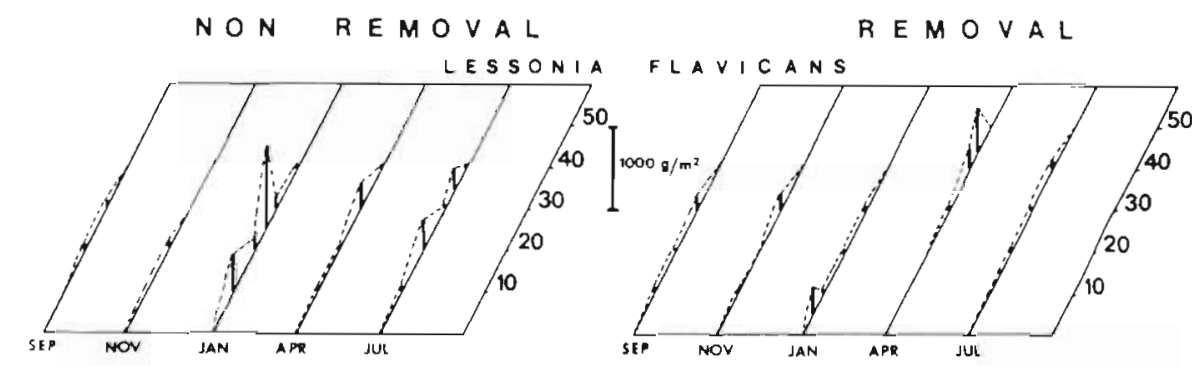

REMOVAL
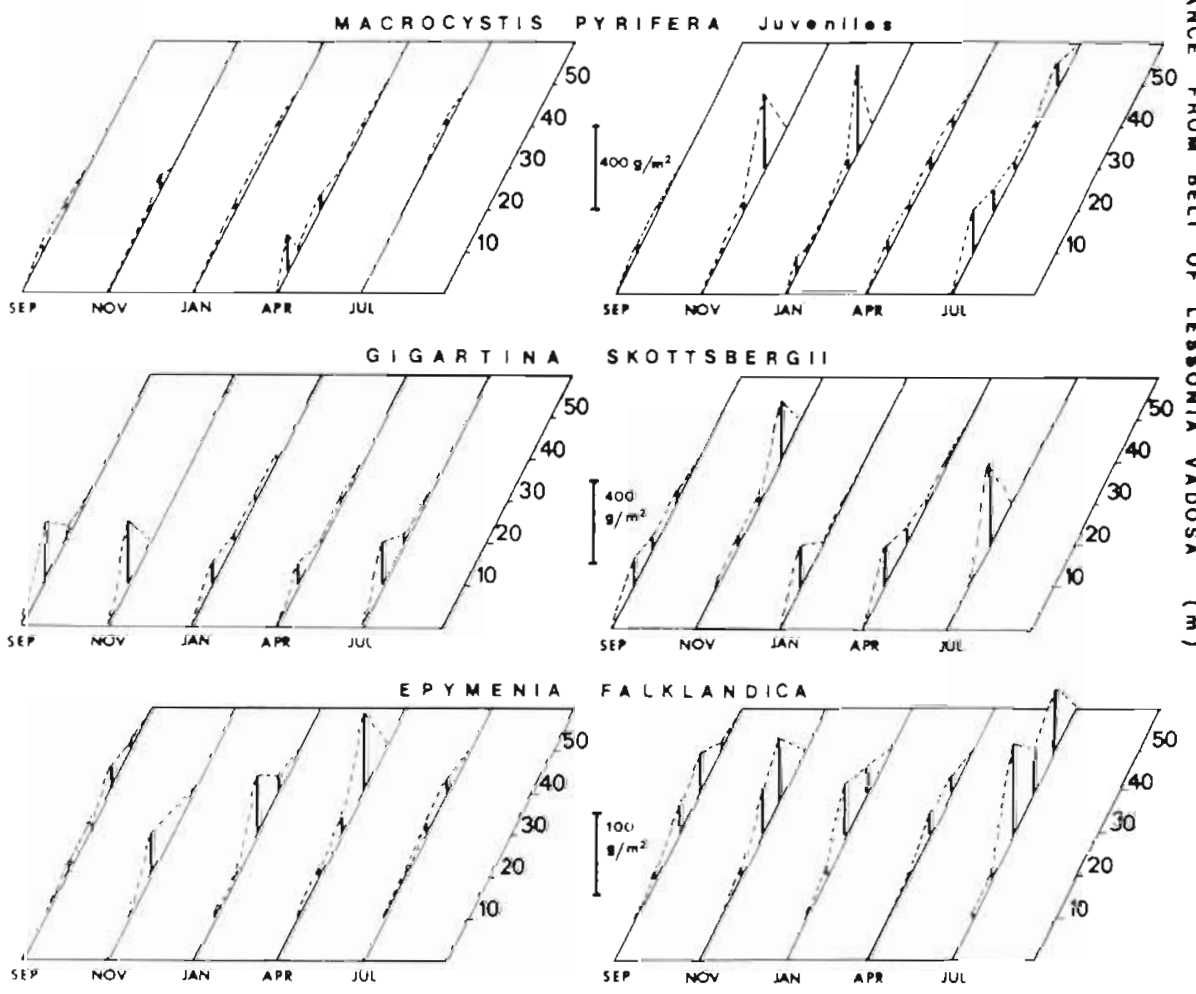

Fig. 3. Spatial and temporal changes in distribution of 4 understory algal species in the forest of Macrocystis pyrifera in Puerto Toro, Navarino Island 


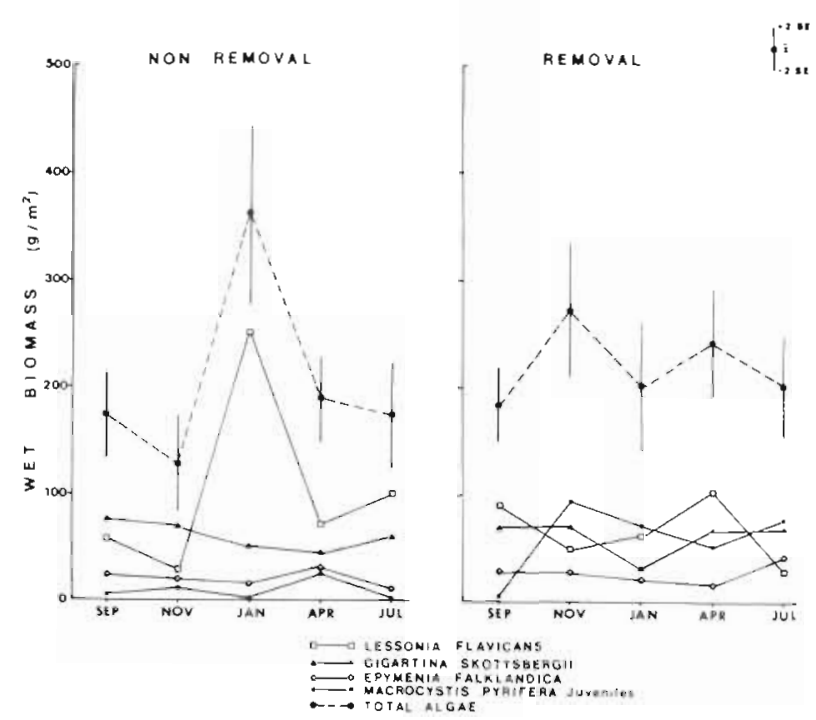

Fig. 4. Temporal changes in wet biomass of understory algal species in areas of the forest of Macrocystis pyrifera with and without removal of floating canopy. Removal of the floating canopy was performed in early November; data in biomass distribution were gathered in late November

(McLean, 1962; Neushul, 1971; Foster, 1975a), it has a reduced algal species richness as compared with its northern hemisphere counterparts (North, 1971). This phenomenon was already noted by Dayton et al. (1973) who commented on the absence of ecological equivalents (other than Lessonia flavicans) of the several Laminariales which in the North Pacific form the first and second vegetational strata. It is clear now that the reduced species richness is also exhibited by most fish and invertebrate groups found in the southern forests (Santelices et al., 1981; Ojeda and Santelices, in preparation).

The response shown by Lessonia flavicans to the removal of the floating canopy of Macrocystis pyrifera was unexpected, considering equivalent experiments in the North Pacific (Dayton, 1975a; Pearse and Hines, 1979; Reed and Foster, in press), which indicate that species in the second vegetational stratum normally increase in cover and biomass after canopy removal. In Puerto Toro, by contrast' such a removal resulted in reduction of the biomass of $L$. flavicans. Field observations indicate that juvenile recruitment of $L$. flavicans indeed occurred immediately after the removal of $M$. pyrifera, however, most of these plants die or disappear from November to January. Thus, the main biomass difference found between the 2 transects in January resulted from the continued growth of L. flavicans juveniles in the non-removal transect. We were unable to determine whether the limited growth of these juveniles in the removal transect was due to competitive interactions for space or light with juveniles of $M$. pyrifera, to the bleaching effects produced by increased light intensity or to other causes.

The increments of foliose and filamentous understory species (especially red algae) generally reported in the Californian experiments after removal of the floating canopy of Macrocystis pyrifera (North, 1971; Dayton, 1975a; Pearse and Hines, 1979) were not obvious in Puerto Toro, and the species turnover there seems complex. Our results parallel some of the results gathered by Dayton (1975b) in intertidal (Hedophyllum) communities of the North Pacific but there are also clear differences. Thus, the understory in Puerto Toro includes a number of seemingly 'obligate understory' species which disappear with the removal of the floating canopy. In contrast to what Dayton (1975b) found, these are fugitive species occurring only during a few months in the year. Furthermore, they are replaced by a group of species, also fugitive, which could be found only in the area without canopy. It is not clear, therefore, if this obligate understory dies by increased light intensity after the removal of the canopy or if it is competitively excluded by the second group of fugitive species. It could be argued that these species have a patchy distribution in the forest both in space and time and that our results only reflect sampling artifacts. However, the presence/absence data for each species are based on twenty $1 \mathrm{~m}^{2}$ quadrats placed every $5 \mathrm{~m}$ along the $50 \mathrm{~m}$ long transect, which should be adequate to compensate for patchy distribution in space.

The response shown by the most permanent species of the third stratum was also unexpected. These species are not patchy either in space or in time and their occurrence seems unaffected by light intensity changes due either to season or to removal of the floating canopy. Species with this characteristic have not been reported in similar experiments elsewhere (Dayton, 1975a, b; Pearse and Hines, 1979). In Puerto Toro they are the most important producers in the third stratum. It is interesting to notice that biomass distribution of some of these species clearly point to the possibility of competitive interactions, as between Gigartina skottsbergii and Epymenia falklandica, which seems to be related to space and substratum utilization rather than to light trapping. Even though we do not have experimental data, field observations indicate $G$. skottsbergii occurs mainly on compact, consolidated rocky bottoms where the normally horizontally extended, heavy and fleshy frond can attach itself by a number of peg-like projections. Such a bottom occurs mainly in the first half of the forest (Santelices and Ojeda, 1983). The rocky bottom become dissected in the second, deeper part of the forest. The heavy fronds of $G$. skottsbergii are probably dislodged more easily by water movement from this last area, thus allowing 
the growth of E. falklandica. Experimental data are still needed to test this interaction.

Our results indicate that it is difficult to conclude unequivocally if Macrocystis pyrifera in the forests of Puerto Toro could be considered a 'foundation species' (Dayton, 1972) as Barrales and Lobban (1975) uncritically suggested for an Argentinian forest. Dayton's definition has at least 2 components. First, the species has to influence the community in a way which is out of proportion with its descriptive importance (measured as cover, biomass, frequency or in any other way). Since $M$. pyrifera has a disproportionally high standing stock contribution to this community, any effect produced by the removal of the canopy, no matter how important it would be, would be proportional to the very high descriptive representation of this species.

The second component of Dayton's definition is that the removal of this species should produce a significant change in the resulting community structure. We did not remove the whole plants of Macrocystis pyrifera but experimentally removed the floating canopy which in comparable experiments in North America has been shown to have significant ecological importance. The results indicate changes which vary in importance according to the aspect considered. The removal of the canopy reduced the standing stock of the second stratum but did not do so in the third stratum. It affected the time-space distributional pattern of most fugitive species but did not change the distribution of the most permanent members of the community. It changed species composition but did not change total species richness. With all these data it is difficult for us to recognize the understory algal community growing in the removal area as objectively different from the one occurring in the non-removal area.

A related study (Santelices and Ojeda, 1983) shows that Macrocystis pyrifera in Puerto Toro has a growth and reproduction strategy similar to that described from Corona del Mar in the North Pacific. The results gathered in this study indicate that the ecological role of a given species, such as $M$. pyrifera, not only depends on the life strategy of that given species but also on the ecological responses of the other members in the community. In this case, the understory algal community of Puerto Toro behaves differently from the one on the North Pacific, conditioning the resulting ecological importance of the dominant canopy.

Acknowledgements. This report is part of a comprehensive study on the biology and utilization of Macrocystis pyrifera in southern Chile. The work was financed through a Research Grant agreed on between the Armada de Chile and the Pontificia Universidad Católica de Chile. We thank R. Bravo, G. Casanova, J. C. Castilla, H. Castillo, A. Jullian, A. Larrea, C. Moreno and J. Vásquez for much help in the field, and J.
Pearse for critically reading the manuscript. Advice and criticism of the 3 reviewers (P. Dayton, J. Estes and D. Reed) improved the manuscript and are acknowledged with gratitude. We are thankful of D. Reed and M. Foster for allowing us to see their manuscript in press.

\section{LITERATURE CITED}

Aleem, A. A. (1956). A quantitative study of the benthics communities inhabiting the kelp beds off the California coast, with a self-contained diving apparatus. Proc. 2nd Int. Seaweed Symp. Pergamon Press, Oxford, p. 149-151

Aleem, A. A. (1973). Ecology of a kelp bed in southern California. Botanica mar. 16: 83-95

Andrews, H. L. (1945). The kelp beds of the Monterrey region. Ecology 26: 24-37

Barrales, H. L., Lobban, C. S. (1975). The comparative ecology of Macrocystis pyrifera, with emphasis on the forest of Chubut, Argentina. J. Ecol. 63: 657-677

Cribb, A. B. (1954). Macrocystis pyrifera (L.) Ag. in Tasmanian waters. Aust. J. mar. Freshwat. Res. 5: 1-34

Dayton, P. K. (1972). Toward an understanding of community resilience and the potential effects of enrichments to the benthos at McMurdo Sound, Antarctica. In: Parker, B. C. (ed.) Proc. Colloq. Conserv. Probl. Antarctic. Virginia Polytech. Inst. and State Univ. Blacksbury, Virginia, p. 81-95

Dayton, P. K. (1974). Kelp communities of southern South America. Antarct. J. U. S. 9: 22

Dayton, P. K. (1975a). Experimental studies of algal canopy interactions in a sea otter-dominated kelp community at Amchitka Island, Alaska. Fish. Bull. U.S. 73: 230-237

Dayton, P. K. (1975b). Experimental evaluation of ecological dominance in a rocky intertidal algal community. Ecol. Monogr. 45: 137-159

Dayton, P. K., Rosenthal, R. J., Mahan, L. C. (1973). Kelp communities in the Chilean Archipelago: R/V Hero cruise 72-5. Antarct. J. U.S. 8: 34-35

Dawson, E. Y., Neushul, M., Wildman, R. D. (1960). Seaweeds associated with kelp beds along southern California and northwestern Mexico. Pacif. Nat. 1: 1-81

Foster, M. S. (1975a). Regulation of algal community development in a Macrocystis pyrifera forest. Mar. Biol. 32: 331-342

Foster, M. S. (1975b). Algal succession in a Macrocystis pyrifera forest. Mar. Biol. 32: 313-329

Kühnemann, O. (1970). Algunas consideraciones sobre los bosques de Macrocystis pyrifera. Physis 29: 273-296

McLean, J. H. (1962). Sublittoral ecology of kelp beds of the open coast area near Carmel, California. Biol. Bull. mar. biol. Lab., Woods Hole 122: 95-114

Neushul, M. (1971). Submarine illumination in kelp beds. In: North, W. J. (ed.) The biology of giant kelp beds (Macrocystis) in California. Nova Hedwigia 32: 241-254

North, W. J. (1968). Effects of canopy cutting on kelp growth: comparison of experimentation with theory. In: North, W. J., Hubbs, C. L. (ed.) Utilization of kelp-bed resources in Southern California. Fish. Bull. Calif. 139: 223-254

North, W. J. (1971). Introduction and background. In: North, W. J. (ed.) The biology of giant kelp beds (Macrocystis) in California. Nova Hedwigia 32: 1-96

Pearse, J. S., Hines, A. H. (1979). Expansion of a central California kelp forest following the mass mortality of sea urchins. Mar. Biol. 51: 83-91

Reed, D. C., Foster, M. S. (in press). The effects of canopy 
shading on algal recruitment and growth in a giant kelp forest. Ecology

Santelices, B., Castilla, J. C., Moreno, C. (1981). Macrocystis pyrifera communities from southern South America. Differences with the Northern Pacific. Abstracts XIII International Botanical Congress, Sidney, Australia

Santelices, B., Ojeda, F. P. (1983). Population dynamics of coastal forests of Macrocystis pyrifera in Puerto Toro, Isla Navarino, Southern Chile. Mar. Ecol. Prog. Ser. 14: 175-183

Yellin, M. B., Agegian, C. R., Pearse, J. S. (1977). Ecological benchmarks in the Santa Cruz County kelp forests before the re-establishment of sea otters. Univ. of California, Stn Cruz, Center for Coastal Marine Studies. Tech. Rep. 6: $1-125$

This paper was presented by Professor J. S. Pearse; it was accepted for printing on July 29, 1983 